\title{
Evaluasi Pengelolaan Lansekap Pura Mengening, Desa Pakraman Saraseda, Kecamatan Tampaksiring, Kabupaten Gianyar, Provinsi Bali
}

\author{
KADEK AYU DIAH UTAMII ${ }^{1}$, SANG MADE SARWADANA ${ }^{1 *}$, \\ ANAK AGUNG GEDE DALEM SUDARSANA ${ }^{1}$
}

1. Program Studi Arsitektur Pertamanan, Fakultas Pertaniaan, Universitas Udayana, Denpasar, 80114, Indonesia

*Email: sarwadana55@gmail.com

\begin{abstract}
Evaluation of Landscape Management in Mengening Temple, Saraseda Village, District of Tampaksiring, Gianyar Regency, Province of Bali.
\end{abstract}

Mengening temple is one of the cultural landscape that has malukat area but less affirmed malukat area with the washing area for residents and inadequate facilities are problems in the site. This research aims to determine the landscape management applied in Mengening temple. The method used in this research was survey method with observation, questionnaires, interviews, and literature study. The results of this study was a description of management applied by member of Saraseda village sescription of potentials and issues of landscaping management of Mengening temple in terms of management, space, structuring, and maintenance, along with descriptions of recommended efforts that can be done to improve the quality of management and recommendations for a workable floor plan. This recommendation given in the form of inputs that can be done to the government, managers, and the community so that it can be improve the quality of the Mengening temple management and maintain the sanctity and holiness of Mengening temple.

Keywords: pakraman village, evaluation of landscape management, cultural landscape, Mengening temple.

\section{Pendahuluan}

Banyak sebutan untuk Pulau Bali yang telah tersebar di masyarakat domestik maupun mancanegara. Salah satunya adalah Pulau Seribu Pura. Sebutan ini dikarenakan banyaknya jumlah pura yang ada di Bali sebagai tempat ibadah pemeluk agama Hindu yang merupakan mayoritas agama yang terdapat di Bali yakni 84,5\% dari 4.152.8000 jiwa penduduk Bali (Badan Pusat Statistik Provinsi Bali, 2015). Keberadaan pura-pura ini tersebar di seluruh kabupaten dan kotamadya yang terdapat di Bali, salah satunya berada di Kabupaten Gianyar, yakni Pura Mengening.

Pura Mengening merupakan Pura Dang Kahyangan atau Pura Kahyangan Jagat. Pura Mengening terletak sebelah Selatan obyek wisata Tirta Empul. Pura Mengening merupakan salah satu contoh lansekap budaya yang sudah ada sejak raja Masula-Masuli 
memerintah di Pejeng yakni sekitar abad XI (Sudiartama, 2012). Pura Mengening merupakan Pura yang memiliki area malukat (pembersihan dan penyucian diri), namun terdapat permasalahan yakni kurang dipertegasnya fungsi area tersebut. Banyak terdapat warga setempat yang melakukan kegiatan mandi pada area malukat dan kurang memadainya fasilitas yang terdapat di kawasan Pura Mengening.

Evaluasi pengelolaan lansekap budaya Pura Mengening diangkat menjadi topik penelitian dengan tujuan untuk mengetahui pengelolaan lansekap Pura Mengening, mengetahui potensi dan permasalahan pengelolaan lansekap Pura Mengening, dan mengetahui usaha-usaha yang dapat dilakukan untuk meningkatkan kualitas pengelolaan lansekap Pura Mengening.

\section{Metode Penelitian}

\subsection{Tempat dan Waktu Penelitian}

Penelitian dilakukan di kawasan Pura Mengening, yang terletak di Desa Pakraman Saraseda, Kecamatan Tampaksiring, Kabupaten Gianyar, Provinsi Bali. Penelitian berlangsung selama 12 bulan yakni Juli 2016 sampai dengan Juni 2017.

\subsection{Alat Penelitian}

Alat yang digunakan dalam penelitian ini adalah kamera, GPS, komputer dengan piranti lunak Google Earth, AutoCAD 2010 dan Adobe Photoshop CS4, serta lembar kuisioner, dan lembar wawancara.

\subsection{Metode Penelitian}

Metode penelitian yang digunakan dalam penelitian ini adalah metode survei dengan teknik pengumpulan data melalui observasi, wawancara, penyebaran kuesioner, dan studi pustaka.

\subsubsection{Observasi}

Metode observasi digunakan untuk mengupulkan data melalui pengamatan langsung di lapangan untuk memperoleh gambaran yang jelas mengenai kawasan Pura Mengening.

\subsubsection{Kuesioner}

Metode kuesioner digunakan untuk mengumpulkan data yang dilakukan untuk memperoleh informasi dengan memberikan angket kepada 30 pengunjung Pura Mengening. Asumsi distribusi normal saat perhitungan ketika jumlah sampel mencapai 30 orang (Reimundo, 2014).

\subsubsection{Wawancara}

Teknik wawancara dilakukan untuk mengumpulkan data yang digunakan dengan mengadakan tanya jawab langsung terhadap Bendesa Adat Desa Pakraman Saraseda selaku ketua pengelola Pura Mengening.

\subsubsection{Studi Pustaka}

Studi pustaka dilakukan untuk memperoleh informasi melalui sumber pustaka sebagai acuan seperti buku, jurnal, makalah dan media internet lain terkait obyek penelitian. 


\subsection{Data Penelitian}

Jenis data yang dikumpulkan dalam penelitian ini adalah data primer dan data sekunder. Data primer merupakan data yang diperoleh peneliti melalui teknik observasi, penyebaran kuesioner, dan wawancara. Data sekunder diperoleh peneliti melalui teknik studi pustaka.

\subsection{Teknik Analisis Data}

Teknik analisis data mengikuti metode yang disampaikan Silalahi (2006) meliputi tahap pengolahan data hasil observasi kuisioner, dan wawancara. Metode yang digunakan adalah tabulasi, analisis spasial, dan analisis deskriptif.

\subsubsection{Tabulasi}

Menurut Sudjana (2001), teknik tabulasi data ini digunakan untuk menghitung jumlah pilihan responden (f) dibandingkan dengan jumlah keseluruhan responden $(\mathrm{N})$ ke dalam bentuk persentase (\%) dengan dikali 100 persen. Perhitungan persentase seperti dikemukanan Sudjana adalah sebagai berikut:

$$
P=f / N \times 100 \%
$$

Keterangan:

$\mathrm{P}=$ Persentase

$\mathrm{f}=$ Frekuensi

$\mathrm{N}=\sum$ Total responden

\subsubsection{Analisis Spasial}

Analisis spasial merupakan analisis untuk mengukur distribusi suatu kejadian berdasarkan aspek keruangan. Analisis spasial akan menghasilkan sebuah denah hasil analisis ruang (Tuman, 2001).

\subsubsection{Analisis Deskriptif}

Teknik analisis yang digunakan adalah menurut Sugiyono (2004) yaitu analisis deskriptif. Metode ini digunakan untuk menganalisis data dengan cara mendeskripsikan atau menggambarkan data yang telah terkumpul.

\subsection{Batasan Penelitian}

Penelitian terbatas pada pengelolaan yang diterapkan pada lansekap Pura Mengening, potensi dan permasalahan pengelolaan lansekap Pura Mengening, dan usaha-usaha yang harus dilakukan untuk meningkatkan kualitas pengelolaan Pura Mengening.

\section{Hasil dan Pembahasan}

\subsection{Hasil}

\subsubsection{Gambaran Umum Lokasi Penelitian}

Pura Mengening terletak di Desa Pakraman Saraseda, Kecamatan Tampaksiring, Kabupaten Gianyar, Provinsi Bali, sebelah Selatan kawasan Pura Tirta Empul. Luas wilayah kawasan Pura Mengening adalah 4,5 ha dengan ketinggian $350 \mathrm{~m}$ dpl. 


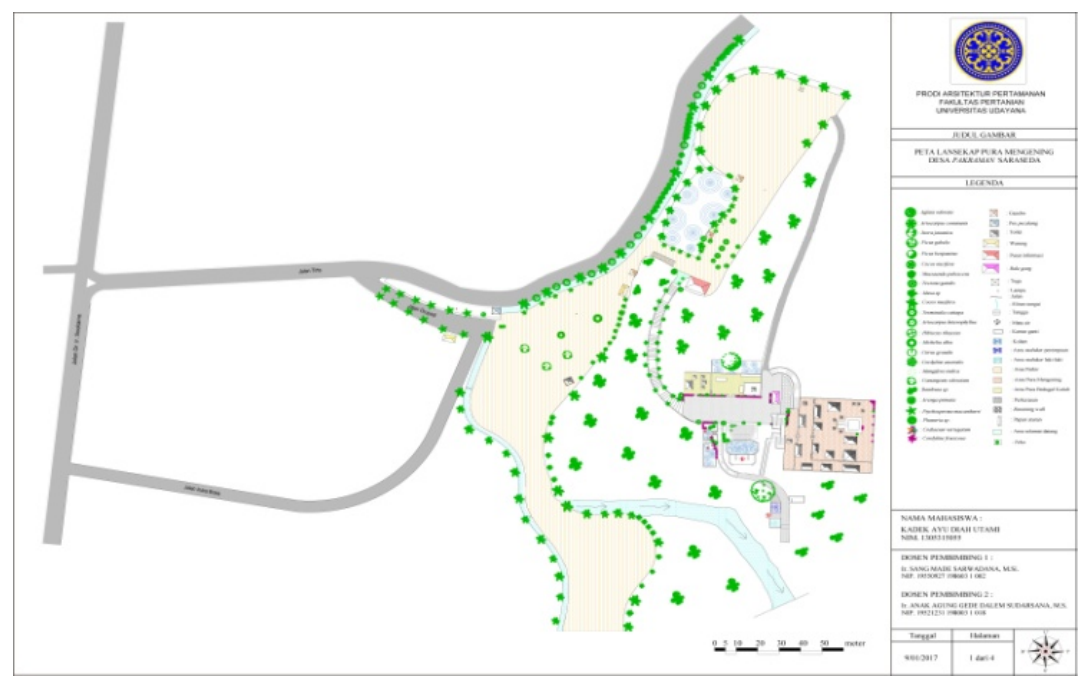

Gambar 1. Denah Eksisting Kawasan Pura Mengening

(Sumber: Pengolahan Data, 2016)

\subsubsection{Pengelolaan yang Diterapkan pada Lansekap Pura Mengening}

\subsubsection{Pengelolaan}

Pengelolaan lansekap Pura Mengening meliputi sumber daya manusia, alat, pendanaan, dan pengawasan.

\section{a. Sumber daya manusia}

Pengelolaan yang diterapkan pada lansekap Pura Mengening adalah pengelolaan yang dikelola oleh Desa Pakraman Saraseda, melibatkan 48 orang masyarakat.

b. Alat

Alat kebersihan yang dimiliki oleh pengelola untuk kegiatan kebersihan sehari-hari dapat adalah sapu lidi empat buah, sapu ijuk dua buah, serok dua buah, selang satu buah, dan satu buah motor pembawa sampah.

c. Pendanaan

Total pemasukan dana pengelolaan setiap enam bulan sekali adalah Rp.100.400.000. Total pengeluaran setiap enam bulan sekali adalah Rp.100.400.000.

d. Pengawasan

Kegiatan pengawasan pada pengelolaan lansekap meliputi kegiatan pengawasan di lapang setiap hari dan evaluasi dalam rapat di Banjar Saraseda sebulan sekali.

\subsubsection{Pola ruang}

Ruang yang terdapat di kawasan Pura Mengening meliputi tiga ruang atau zona yaitu zona inti, zona penyangga, dan zona pengembang.

\subsubsection{Penataan}

\section{a. Sirkulasi}

Sirkulasi di kawasan Pura Mengening meliputi sirkulasi kendaraan dan sirkulasi pejalan kaki. 


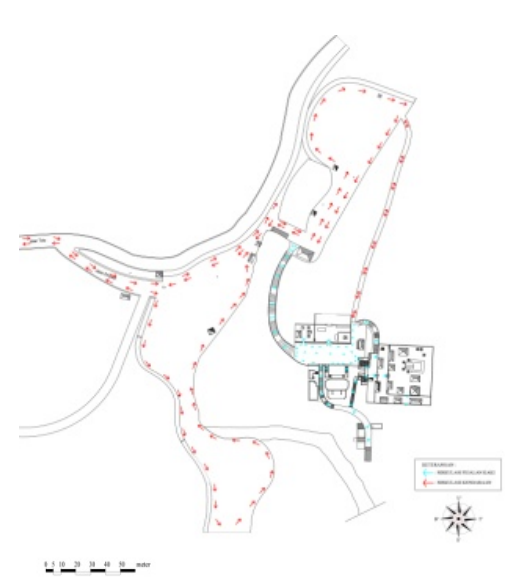

Gambar 2. Sirkulasi di Kawasan Pura Mengening

Keterangan : Pengolahan data, 2016

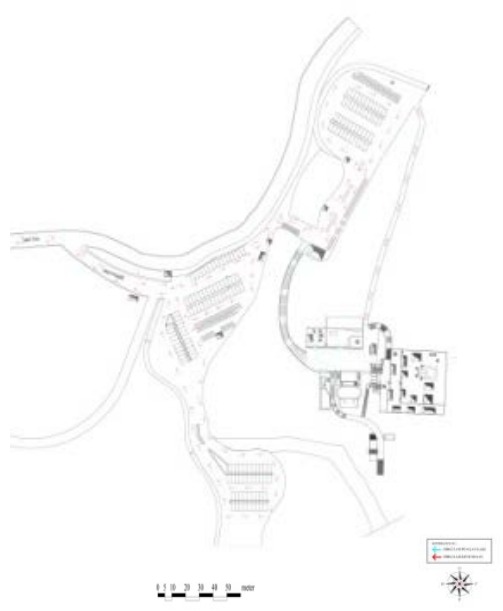

Gambar 3. Rekomendasi Sirkulasi di Kawasan Pura Mengening

Keterangan : Pengolahan data, 2016

b. Elemen lunak

Elemen lunak meliputi 27 jenis tanaman dengan letak tanaman tidak ditata secara khusus, sehingga diberikan rekomendasi penataan tanaman di zona inti dan penyangga Pura Mengening.

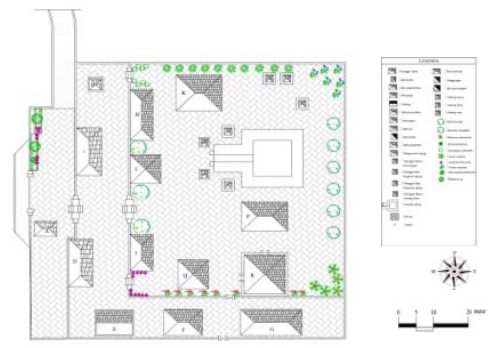

Gambar 4.. Rekomendasi Penataan Tanaman di Zona Inti

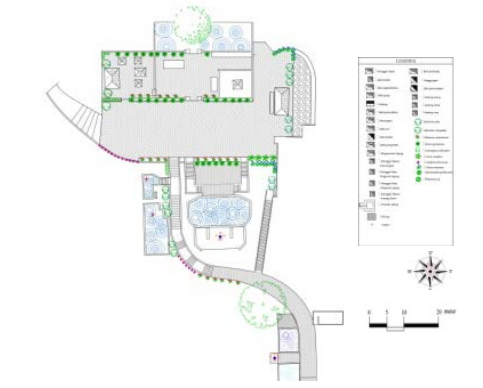

Gambar 5. Rekomendasi Penataan Tanaman di Zona Penyangga

\section{c. Elemen keras}

Elemen keras di kawasan Pura Mengening meliputi tangga, jalan setapak, paving, kolam malukat, kolam penirtaan, kolam ikan, keran air, lampu taman, pelinggih, papan aturan, papan nama Pura Mengening, papan kawasan DAS Pakerisan, tempat sampah, Candi Prasada Agung, Pangaruman Agung, Pewaregan, bale, gudang, toilet, pusat informasi, pos pecalang, gazebo, dan kamar ganti.

d. Fasilitas

Fasilitas yang terdapat di kawasan Pura Mengening meliputi tempat parkir, toilet, pusat informasi, tempat malukat, kamar ganti, tempat sembahyang, gazebo, warung, kain, dan selendang. 


\subsubsection{Pemeliharaan}

Pemeliharaan lansekap Pura Mengening meliputi kegiatan bersih-bersih pemeliharaan tanaman, dan pemeliharaan elemen keras. Kapasitas kerja pemeliharaan taman Pura Mengening dapat dilihat dalam Tabel 1. Berikut :

Tabel 1. Kapasitas Kerja Pemeliharaan Taman Pura Mengening dan Standar Kapasitas Kerja Pemeliharaan Taman

\begin{tabular}{|c|c|c|c|c|c|c|c|c|}
\hline No & $\begin{array}{c}\text { Jenis } \\
\text { Pekerjaan }\end{array}$ & $\begin{array}{l}\text { Jumlah } \\
\text { Pekerja } \\
\text { (orang) }\end{array}$ & $\begin{array}{l}\text { Luas } \\
\text { Area } \\
\left(\mathrm{m}^{2}\right)\end{array}$ & $\begin{array}{c}\text { Wakt } \\
\text { u } \\
\text { (Jam) }\end{array}$ & $\begin{array}{l}\text { Kapasitas } \\
\text { Kerja (a) } \\
\left(\mathrm{m}^{2} / \mathrm{jam}\right)\end{array}$ & $\begin{array}{l}\text { Kapasitas } \\
\text { Kerja (b) } \\
\left(\mathrm{m}^{2} / \mathrm{jam}\right)\end{array}$ & $\begin{array}{c}\text { Frekuensi } \\
\text { Pemeliharaan } \\
\text { Musim Kemarau }\end{array}$ & $\begin{array}{c}\text { Frekuensi } \\
\text { Pemeliharaan } \\
\text { Musim Hujan }\end{array}$ \\
\hline 1 & Menyapu & 6 & 25.000 & 6 & 694 & 800 & Setiap hari & Setiap hari \\
\hline 2 & Menyiram & 3 & 3500 & 2 & 583 & 700 & 2 hari 1 kali & Insidentil \\
\hline 3 & Memupuk & Insidentil & 3500 & - & - & - & Insidentil & Insidentil \\
\hline 4 & Pemangkasan & Insidentil & 3500 & - & - & - & Insidentil & Insidentil \\
\hline 5 & $\begin{array}{l}\text { Pemeliharaan } \\
\text { elemen keras }\end{array}$ & Insidentil & & & & & Insidentil & Insidentil \\
\hline
\end{tabular}

Keterangan: (a) Pengamatan lapang di kawasan Pura Mengening, 2016

(b) Kapasitas Kerja Pemeliharaan Taman (Arifin dan Arifin, 2005)

\subsubsection{Potensi dan Permasalahan Pengelolaan yang Diterapkan pada Lansekap}

Pura Mengening

Potensi dan permasalahan pengelolaan lansekap Pura Mengening diperoleh dengan melakukan analisis terhadap pengelolaan lansekap Pura Mengening, evaluasi pengunjung mengenai kondisi di Pura Mengening, serta membandingkan dengan pengelolaan yang diterapkan di kawasan Pura Tirta Empul. Perbandingan ini dikarenakan Pura Mengening dan Pura Tirta Empul merupakan Cagar Budaya peninggalan DAS Pakerisan yang pelestarian dan pemanfaatannya sama-sama dilindungi oleh UndangUndang Nomor 11 tahun 2010 serta keduanya memiliki fungsi yang sama sebagai tempat sembahyang dan terdapat tempat malukat.

Tabel 2. Hasil Evaluasi Pengunjung di Kawasan Pura Mengening

\begin{tabular}{|c|c|c|c|c|c|c|c|}
\hline No & Pertanyaan & A & B & $\mathrm{C}$ & D & $\mathrm{E}$ & Total \\
\hline 1 & $\begin{array}{l}\text { Kenyamanan (adanya } \\
\text { vegetasi pada tapak) }\end{array}$ & $\begin{array}{c}\text { Sangat } \\
\text { nyaman } \\
40 \%\end{array}$ & $\begin{array}{c}\text { Nyaman } \\
47 \%\end{array}$ & $\begin{array}{c}\text { Cukup } \\
\text { nyaman } \\
10 \%\end{array}$ & $\begin{array}{c}\text { Kurang } \\
\text { nyaman } \\
3 \%\end{array}$ & $\begin{array}{c}\text { Tidak } \\
\text { nyaman } \\
0 \%\end{array}$ & $100 \%$ \\
\hline 2 & Ketersediaan fasilitas & $\begin{array}{c}\text { Sangat } \\
\text { lengkap } \\
17 \%\end{array}$ & $\begin{array}{c}\text { Lengkap } \\
20 \%\end{array}$ & $\begin{array}{c}\text { Cukup } \\
\text { lengkap } \\
33 \%\end{array}$ & $\begin{array}{c}\text { Kurang } \\
\text { lengkap } \\
27 \%\end{array}$ & $\begin{array}{c}\text { Tidak } \\
\text { lengkap } \\
3 \%\end{array}$ & $100 \%$ \\
\hline 3 & Kondisi fasilitas & $\begin{array}{c}\text { Sangat } \\
\text { baik } \\
17 \%\end{array}$ & $\begin{array}{l}\text { Baik } \\
37 \%\end{array}$ & $\begin{array}{c}\text { Cukup } \\
\text { baik } \\
33 \%\end{array}$ & $\begin{array}{c}\text { Kurang } \\
\text { baik } \\
13 \%\end{array}$ & $\begin{array}{c}\text { Tidak } \\
\text { baik } \\
0 \%\end{array}$ & $100 \%$ \\
\hline 4 & $\begin{array}{l}\text { Mengetahui keberadaan } \\
\text { Pura Mengening }\end{array}$ & $\begin{array}{c}\text { Keluarga } \\
43 \% \\
\end{array}$ & $\begin{array}{c}\text { Teman } \\
30 \% \\
\end{array}$ & $\begin{array}{c}\text { Media } \\
\text { sosial } \\
17 \% \\
\end{array}$ & $\begin{array}{c}\text { Media } \\
\text { cetak } \\
10 \% \\
\end{array}$ & $\begin{array}{c}\text { Media } \\
\text { elektronik } \\
0 \% \\
\end{array}$ & $100 \%$ \\
\hline 5 & Keamanan & $\begin{array}{c}\text { Sangat } \\
\text { aman } \\
37 \%\end{array}$ & $\begin{array}{c}\text { Aman } \\
43 \%\end{array}$ & $\begin{array}{c}\text { Cukup } \\
\text { aman } \\
13 \%\end{array}$ & $\begin{array}{c}\text { Kurang } \\
\text { aman } \\
7 \%\end{array}$ & $\begin{array}{c}\text { Tidak } \\
\text { aman } \\
0 \%\end{array}$ & $100 \%$ \\
\hline
\end{tabular}

Keterangan : Survei, 2016

\subsubsection{Pengelolaan}

a. Sumber daya manusia

Sistem pengelolaan Pura Tirta Empul dikelola oleh Desa Adat Manukaya dan Dinas Pariwisata Kabupaten Gianyar dengan melibatkan 100 KK Desa Adat Manukaya 
dan 15 orang PNS Dinas Pariwisata Kabupaten Gianyar. Pengambilan keputusan secara aklamasi dan secara demokrasi.

b. Alat

Alat-alat kebersihan yang dimiliki pengelola Pura Tirta Empul adalah sapu lidi, sapu ijuk, serok, tempat sampah, tempat sampah toilet, keset, sabun cair, tisu toilet, bahan pembersih wc, pengharum ruangan, sikat wc, lap pel, pisau cukur rumput, alat pel lantai, keranjang sampah, dan ember. Alat-Alat tersebut berasal dari Dinas Pariwisata Kabupaten Gianyar.

\section{c. Pendanaan}

Dana yang diperoleh pengelola Pura Tirta Empul melalui pemasukan tiket pengunjung, pemasukan parkir, dan anggaran Pendapatan Belanja Daerah (APBD) Kabupaten Gianyar yang diberikan setahun sekali sebesar Rp. 100.000.000.

d. Pengawasan

Pengawasan pengelolaan Pura Tirta Empul meliputi kegiatan pengawasan yang dilakukan setiap hari pengelola dan pegawai Dinas Pariwisata Kota Gianyar yang bertugas di kawasan Pura Tirta Empul.

\subsubsection{Pola ruang}

Terdapat permasalahan pada zona penyangga yakni terdapat tempat malukat namun kurang dipertegas fungsi tempat malukat tersebut karena tidak sedikit masyarakat Desa Pakraman Saraseda menggunakan tempat malukat tersebut sebagai tempat mandi. Permasalahan tersebut dapat diatasi dengan menerapkan pemanfaatan ruang seperti pada Gambar 6. berikut:

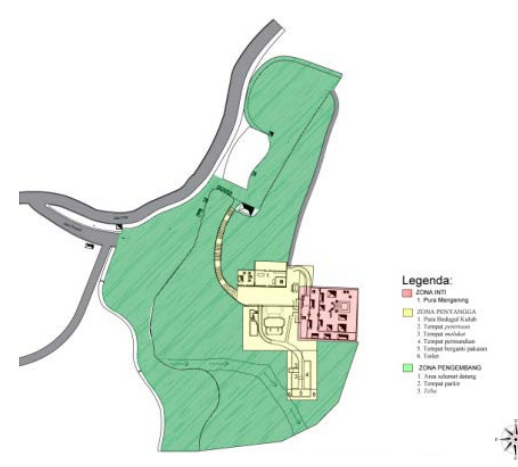

Gambar 6.Rekomendasi Pemanfaatan Ruang Kawasan Pura Mengening Keterangan : Pengolahan data, 2016

\subsubsection{Penataan}

Pola sirkulasi kendaraan dan pejalan kaki di kawasan Tirta Empul lebih jelas dibanding pola sirkulasi di kawasan Pura Mengening karena terdapat penunjuk arah atau jalan. Tanaman yang tumbuh di Pura Tirta Empul sangat ditata keberadaanya. Beberapa tanaman kawasan Pura Tirta Empu Idiberi identitas berupa nama botani dan nama latin. Beberapa elemen keras dan fasilitas di kawasan Pura Mengening mengalami kondisi kurang baik, seperti tangga, toilet, pos pecalang, gazebo, tempat parkir dan kamar ganti.

\subsubsection{Pemeliharaan}

Pemeliharaan lansekap di kawasan Pura Tirta Empul meliputi kegiatan menyapu dan penyiraman tanaman yang dilakukan setiap hari oleh petugas kebersihan dan 
pemeliharan tanaman kegiatan seperti pemupukan dan pemangkasan dilakukan menurut kepentingan. Kegiatan tersebut dibantu oleh dinas terkait.

\subsubsection{Usaha-Usaha yang Dilakukan untuk Meningkatkan Kualitas Pengelolaan Lansekap Pura Mengening \\ Usaha-usaha tersebut berdasarkan hasil penyebaran kuesioner kepada pengunjung untuk meningkatkan kualitas pengelolaan Pura Mengening.}

Tabel 3. Usaha yang Dilakukan untuk Meningkatkan Kualitas Pengelolaan

Lansekap Pura Mengening

\begin{tabular}{|c|c|c|c|c|c|c|c|}
\hline No & Kegiatan & SS & S & KS & TS & STS & Total \\
\hline 1 & Pemisahan area malukat dan mandi & $70 \%$ & $27 \%$ & $3 \%$ & $0 \%$ & $0 \%$ & $100 \%$ \\
\hline 2 & Penambahan tanaman peneduh di area Parkir & $47 \%$ & $40 \%$ & $13 \%$ & $0 \%$ & $0 \%$ & $100 \%$ \\
\hline 3 & $\begin{array}{l}\text { Penambahan tanaman air di kolam yang berada di } \\
\text { kawasan Pura Mengening }\end{array}$ & $33 \%$ & $60 \%$ & $7 \%$ & $0 \%$ & $0 \%$ & $100 \%$ \\
\hline 4 & Pembuatan jalur untuk kursi roda/disabilitas & $30 \%$ & $60 \%$ & $7 \%$ & $3 \%$ & $0 \%$ & $100 \%$ \\
\hline 5 & Pembuatan toilet & $53 \%$ & $40 \%$ & $7 \%$ & $0 \%$ & $0 \%$ & $100 \%$ \\
\hline 6 & Pembuatan loker barang & $43 \%$ & $47 \%$ & $7 \%$ & $3 \%$ & $0 \%$ & $100 \%$ \\
\hline 7 & Penambahan petugas kebersihan & $47 \%$ & $50 \%$ & $3 \%$ & $0 \%$ & $0 \%$ & $100 \%$ \\
\hline 8 & Penambahan tempat sampah & $40 \%$ & $57 \%$ & $0 \%$ & $3 \%$ & $0 \%$ & $100 \%$ \\
\hline 9 & Perbaikan tangga & $23 \%$ & $67 \%$ & $10 \%$ & $0 \%$ & $0 \%$ & $100 \%$ \\
\hline 10 & Perbaikan kamar ganti & $60 \%$ & $37 \%$ & $0 \%$ & $3 \%$ & $0 \%$ & $100 \%$ \\
\hline 11 & Penambahan kamera cctv & $37 \%$ & $37 \%$ & $23 \%$ & $3 \%$ & $0 \%$ & $100 \%$ \\
\hline 12 & Penambahan petugas parkir & $33 \%$ & $50 \%$ & $17 \%$ & $0 \%$ & $0 \%$ & $100 \%$ \\
\hline 13 & Penambahan petugas pemberi informasi (guide) & $57 \%$ & $33 \%$ & $10 \%$ & $0 \%$ & $0 \%$ & $100 \%$ \\
\hline 14 & $\begin{array}{l}\text { Penambahan rambu-rambu di kawasan Pura } \\
\text { Mengening }\end{array}$ & $33 \%$ & $57 \%$ & $0 \%$ & $10 \%$ & $0 \%$ & $100 \%$ \\
\hline 15 & $\begin{array}{l}\text { Penambahan tanaman berbunga di kawasan suci Pura } \\
\text { Mengening. }\end{array}$ & $50 \%$ & $47 \%$ & $0 \%$ & $3 \%$ & $0 \%$ & $100 \%$ \\
\hline
\end{tabular}

\subsection{Pembahasan}

\subsubsection{Pengelolaan yang Diterapkan pada Lansekap Pura Mengening}

Pengelolaan dilakukan dengan sistem demokrasi. Pengelolaan lansekap Pura Mengening dengan sistem demokrasi yakni semua pelaksanaan pengelolaan termasuk pengambilan keputusan serta pembuatan aturan berdasarkan keputusan bersama anggota pengelola. Kegiatan pengawasan yang dilakukan prajuru adat dalam mengawasi pekerjaan pengelola harus ada SOP, namun belum ada SOP untuk pengelolaan Pura Mengening. Tujuan SOP adalah untuk menjelaskan alur tugas, wewenang, dan tanggung jawab dari petugas yang terkait (Hartatik, 2014).

Sirkulasi kendaraan dan sirkulasi pejalan kaki di Pura Mengening kurang jelas karena tidak adanya penunjuk pengarah jalan (Gambar 2). Rekomendasi perubahan sirkulasi kendaraan pada area parkir supaya sirkulasi kendaraan lebih teratur serta rekomendasi sirkulasi pejalan kaki di area penyangga yang menyesuaikan dengan tahapan kegiatan malukat serta sembahyang di kawasan Pura Mengening (Gambar 3). Penempatan tanaman di kawasan Pura Mengening tidak ditata secara khusus, tanaman 
yang terdapat di Utama Mandala pada zona inti dapat ditata sesuai konsep Asta Dala (Gambar 4) dan tanaman yang terdapat di Utama Mandala pada zona penyangga dapat ditata sesuai konsep Asta Dala (Gambar 5). Asta Dala merupakan delapan penjuru arah mata angin yaitu Utara, Timur Laut, Timur, Tenggara, Selatan, Barat Daya, Barat, dan Barat Laut (Prajoko, 2012). Beberapa elemen keras dan fasilitas memiliki kondisi yang kurang baik seperti tangga, bangunan pusat informasi, bangunan pos pecalang, gazebo, toilet, dan kamar ganti sehingga perlu dilakukan perbaikan/renovasi.

Kapasitas pemeliharaan taman yang dilakukan di kawasan Pura Mengening, lebih rendah dibandingkan dengan standar kapasitas kerja pemeliharaan taman menurut Arifin dan Arifin (2005) (Tabel 1). Rendahnya kapasitas ini disebabkan karena jumlah pengelola dan waktu pengerjaan yang tidak seimbang, topografi di kawasan Pura Mengening tidak datar, dan pengawasan yang tidak ketat.

\subsubsection{Potensi dan Permasalahan Pengelolaan yang Diterapkan pada Lansekap Pura Mengening \\ Sistem pengelolaan yang diterapkan dalam Pura Mengening semestinya sama} seperti pengelolaan yang diterapkan dalam Pura Tirta Empul, karena sama-sama merupakan Cagar Budaya kabupaten Gianyar. Undang-undang nomor 11 tahun 2010 tentang Cagar Budaya menjelaskan dalam pasal 97 ayat (1), pemerintah dan pemerintah daerah memfasilitasi pengelolaan kawasan Cagar Budaya. Pemerintah telah menerapkan pengelolaan tersebut dalam sistem pengelolaan Pura Tirta Empul. Peralatan kebersihan yang dimiliki untuk kegiatan pemeliharaan lansekap Pura Mengening kurang lengkap dibandingkan dengan peralatan kebersihan yang dimiliki oleh pengelola kawasan Pura Tirta Empul. Total pengeluaran dana pengelolaan Pura Mengening sesuai dengan total pemasukan dana pengelola kawasan Pura Mengening sehingga tidak terdapat dana sisa yang dapat digunakan untuk kegiatan pengelolaan lainnya.

Pengelola Pura Mengening harus bersikap tegas mengenai fungsi tempat malukat, karena menurut lontar Raja Purana Usana Bali area tersebut merupakan area malukat. Solusi untuk masyarakat yang terbiasa mandi di area tersebut adalah, dibuatkan area mandi yang terletak di sebelah Selatan area malukat (Gambar 6). Pola sirkulasi kendaraan dan pejalan kaki di kawasan Pura Tirta Empul lebih jelas dengan pola sirkulasi di kawasan Pura Mengening, karena terdapat penunjuk arah atau jalan, sehingga di kawasan Pura Mengening perlu ditambah penunjuk arah atau jalan. Tanaman di area selamat datang kawasan perlu ditata lebih baik dan dapat diberi keterangan identitas berupa nama botani dan nama latin. Ketersediaan fasilitas yang berjumlah 47 unit di kawasan Pura Mengening menurut 33\% jawaban pengunjung cukup lengkap (Tabel 2), namun masih terdapat fasilitas yang kondisinya kurang baik, sehingga tidak dapat digunakan dan perlu dibenahi.

Tempat parkir di kawasan Pura Mengening kurang tertata karena tidak adanya pembatas, sehingga perlu dibuatkan satuan ruang parkir (SRP) yang merupakan ukuran luas efektif untuk meletakan kendaraan (mobil penumpang, bus/truk, atau sepeda motor) termasuk ruang bebas dan lebar buka pintu (Direktorat Jenderal Perhubungan Darat, 2017). 
Hasil kuesioner jawaban pengunjung mengenai keberadaan Pura Mengening 43\% pengunjung menyatakan, bahwa pengunjung mengetahui keberadaan Pura Mengening dari keluarga (Tabel 2), sehingga kegiatan promosi Pura Mengening perlu ditingkatkan oleh pihak pengelola. Promosi dapat dilakukan melalui media sosial, media cetak, dan juga media elektronik

\subsubsection{Usaha-Usaha yang Dilakukan untuk Meningkatkan Kualitas Pengelolaan Lansekap Pura Mengening \\ Usaha yang dilakukan untuk meningkatkan kualitas pengelolaan lansekap Pura} Mengening adalah pemisahan area malukat dan mandi, dari hasil kuesioner yakni $77 \%$ jawaban responden yakni sangat setuju apabila dilakukan pemisahan area malukat dan mandi (Tabel 3), karena saat ini kegiatan mandi masyarakat Desa Pakraman Saraseda dan malukat masih dalam satu area. Sebesar 53\% jawaban kuesioner responden sangat setuju dilakukan pembuatan toilet (Tabel 3), Pembuatan toilet ini perlu untuk mempermudah pengunjung yang ingin membuang air apabila berada di area malukat atau area sembahyang.

Hasil survei dari jawaban responden, sebanyak 67\% setuju apabila dilakukan perbaikan tangga (Tabel 3), karena tinggi anak tangga yang tidak rata yakni $15 \mathrm{~cm}, 18 \mathrm{~cm}$, dan $30 \mathrm{~cm}$ menyebabkan ketidaknyamanan dialami oleh pengunjung yang menggunakan anak tangga sehingga cepat terasa lelah. Hasil dari jawaban responden sebanyak $60 \%$ sangat setuju apabila dilakukan usaha perbaikan kamar ganti (Tabel 3), karena satu unit kamar ganti yang ada saat ini kurang layak untuk digunakan. Kamar ganti tersebut memiliki tinggi hanya 1,5 meter, tidak adanya pintu dan atap, sehingga kurang aman bagi pengunjung yang akan menggunakannya. Sebesar $57 \%$ jawaban responden menyatakan setuju apabila dilakukan penambahan rambu-rambu di kawasan Pura Mengening (Tabel 3). karena tidak sedikit pengunjung yang merasa kebingungan akibat tidak adanya ramburambu di kawasan Pura Mengening sebagai penunjuk arah atau tempat.

\section{Simpulan dan Saran}

\subsection{Simpulan}

Pengelolaan yang diterapkan pada lansekap Pura Mengening, Desa Pakraman Saraseda, Kecamatan Tampaksiring, Kabupaten Gianyar adalah pengelolaan yang dikelola oleh Desa Pakraman Saraseda dengan sistem demokrasi. Pengelolaan dari segi manajemen, pola ruang, penataan, dan pengawasan sudah berjalan cukup baik, tetapi tidak sebaik pengelolaan lansekap pada kawasan yang sama yang berdekatan yaitu Pura Tirta Empul.

Potensi pengelolaan lansekap Pura Mengening yaitu terlihat pada kegiatan pengawasan yang sudah berjalan baik dan keberadaan vegetasi pada tapak yang membuat nyaman. Permasalahan pengelolaan lansekap Pura Mengening antara lain peralatan kebersihan yang dimiliki kurang lengkap, kurangnya dana pengelolaan, kurang dipertegasnya fungsi tempat malukat, kurangnya rambu-rambu pengarah jalan, beberapa elemen keras dan fasilitas memiliki kondisi yang kurang baik, dan kegiatan pemeliharaan 
kurang efektif, serta belum adanya dokumen tugas pokok dan fungsi (Tupoksi) dan SOP.

Beberapa usaha yang perlu dilakukan untuk meningkatkan kualitas pengelolaan lansekap Pura Mengening adalah pemisahan area malukat dan mandi, penambahan tanaman peneduh di area parkir, penambahan tanaman air di kolam, pembuatan jalur untuk kursi roda, pembuatan toilet, pembuatan loker barang, penambahan petugas kebersihan, penambahan tempat sampah, perbaikan tangga, perbaikan kamar ganti, penambahan kamera cctv, penambahan petugas parkir, penambahan guide, penambahan rambu-rambu, dan penambahan tanaman berbunga sebagai tanaman lansekap Pura Mengening.

\subsection{Saran}

Pemerintah sebaiknya ikut terlibat dalam pengelolaan lansekap Pura Mengening, seperti yang dilakukan pada pengelolaan yang terdapat di Pura Tirta Empul yang merupakan satu kawasan DAS Pakerisan. Pemerintah, sebaiknya juga pemerintah daerah membantu pengelola dalam perumusan Tupoksi dan SOP dalam pengelolaan Pura Mengening sehingga pengelola memiliki pedoman yang lebih baku guna mewujudkan pengelolaan yang baik bagi Pura Mengening, sehingga Pura Mengening dapat terjaga kelestariannya.

Pengelola sebaiknya bekerja sama dengan pemerintah dalam mengelola Pura Mengening dan segera menyusun Tupoksi dan SOP, sehingga mempermudah pengelolaan Pura Mengening nantinya.

Sedangkan masyarakat dapat berperan serta dalam menjaga kelestarian Pura Mengening, dengan aktif dalam kegiatan pemeliharaan Pura Mengening seperti kegiatan bersih-bersih. Masyarakat juga harus ikut menjaga kelestarian dengan tetap mematuhi aturan-aturan yang terdapat dalam kawasan Pura Mengening.

\section{Daftar Pustaka}

Arifin, H.S. dan N.H.S. Arifin. 2005. Pemeliharaan Taman. Penebar Swadaya. Jakarta. 188 hal.

Badan Pusat Statistik Provinsi Bali. 2015. Banyaknya Penduduk Menurut Agama. Badan Pusat Statistik 2015.

Direktorat Jenderal Perhubungan Darat. 2017. Satuan Ruang Parkir. Tersedia secara online di: www.hubdat.dephub.go.id. (diakses 2 Maret 2017).

Hartatik, I.P.2014. Buku Praktis Mengembangkan SDM. Jogjakarta. Laksana. 276 hal.

Prajoko, A. 2012. Pertamanan Tradisional Bali Berlandaskan Unsur Satyam, Siwam, Sundaram Religi dan Usada. Tersedia secara online di: www. Parissweethome.com. (diakses 31 Januari 2017)

Reimundo, R. 2014. Mengapa Jumlah Sampel Minimum 30. Tersedia secara online di: www.raynaldofer rarireimundo.blogspot.co.id. (diakses 28 Mei 2016).

Silalahi, U. 2006. Metode Penelitian Sosial. Unpar Press. Bandung. 311 hal. 
Sudiartama, Gst. 2012. Pura Mengening. Tersedia secara online di: www. wahana08.wordpress.com. (diakses 28 Mei 2016).

Sudjana, D. 2001. Metode Statistika. Tarsito. Bandung. 192 hal.

Sugiyono. 2004. Metode Penelitian Bisnis. CV. Alfabeta. Bandung. 380 hal.

Tuman. 2001. Overview of GIS. Tersedia secara online di: www.gisde velopment.net. (diakses 28 Mei 2016).

Undang-Undang Republik Indonesia No 11 Tahun 2010. Perundangan Tentang Cagar Budaya. Tersedia secara online di: www.setneg.go.id. (diakses 1 Maret 2017). 